\title{
Influence of Organic and Inorganic Sources of Nutrients on Growth, Yield and Economics of Summer Groundnut (Arachis hypogaea L.)
}

\author{
J. P. Joshi* and A. G. Patel \\ Department of Agronomy, C. P. College of Agriculture, S.D. Agricultural University, \\ Sardarkrushinagar- 385 506, Gujarat, India \\ *Corresponding author
}

\begin{abstract}
A B S T R A C T
\section{Keywords}

Groundnut Arachis hypogaea, Organic and Inorganic nutrients

Article Info

Accepted:

20 July 2020

Available Online:

140 August 2020

A field experiment was conducted during summer season of 2018 at Agronomy Instructional Farm, Chimanbhai Patel College of Agriculture, Sardarkrushinagar Dantiwada Agricultural University, Sardarkrushinagar, Gujarat to study the effect of organic and inorganic sources of nutrients on growth, yield and economics of summer groundnut (Arachis hypogaea L.). The experiment consists of ten different treatment combinations for application of recommended dose of nitrogen to summer groundnut i.e $25 \mathrm{~kg}$ nitrogen/ha through different organic source viz.(farm yard manure and vermicompost), inorganic fertilizer along with organic sources, Rhizobium and PSB. The results revealed that the integration of inorganic fertilizers along with seed inoculation of biofertilizers i.e. Rhizobium and PSB recorded significantly the highest pods and haulms yield as compared to rest of treatments combinations. Combined application of $75 \%$ RDN and $25 \%$ RDN through vermicompost or FYM along with seed inoculation of Rhizobium and PSB recorded higher pods and haulms yield and also higher net realization and B: C ratio of summer groundnut.
\end{abstract}

\section{Introduction}

Summer groundnut has emerged as one of the major oilseeds crops in India. The production of groundnut in India is 6.77 million tonnes from 4.56 million hectare area with a productivity of $1486 \mathrm{~kg} / \mathrm{ha}$ (DOA, 2018). Whereas in Gujarat, its productivity is $2140 \mathrm{~kg} / \mathrm{ha}$. Groundnut is popularly known as nuts and is an important legume crops grown in Gujarat, Andhra Pradesh, Tamil Nadu, Karnataka and Maharashtra. The Kernals of groundnut is used for many culinary preparation due to its rich source of oil (45.50
$\%$ and protein. Groundnut is helps in maintaining the soil fertility by fixing the nitrogen symbiotically. The low productivity of the crop is primarily due to uncontrolled climatic conditions, low organic matter in the soil due to low use of organic fertilizers and continuous cropping system. The continuous and imbalance use of chemical fertilizers creates problems in the production potential of summer groundnut. Use of chemical fertilizers in combination of organic manures is required for highe production of groundnut crop and to improve the soil health. Moreover, organic manures are good 
complimentary source of nutrients and improve the efficiency of applied mineral (inorganic) nutrient one hand and improve the physical and biological properties of the soil on other hand. Therefore, judicious and combined use of organic and inorganic sources of plant nutrients plays important role in the econominizing the use of fertilizers under increasing cost of chemical ferti out to find out the effect of organic and inorganic sources of nutrients on growth, yield and economics of summer groundnut.

\section{Materials and Methods}

A field experiment was conducted during summer season of 2018 at Agronomy Instructional Farm, Chimanbhai Patel College of Agriculture, Sardarkrushinagar Dantiwada Agricultural University, Sardarkrushinagar to study the effect of organic and inorganic sources of nutrients on growth, yield and economics of summer groundnut (Arachis hypogaea L.)

The experiment was conducted on loamy sand soil having $\mathrm{pH} 7.42$, organic carbon $(0.23 \%)$ and available nitrogen (158 $\mathrm{kg} / \mathrm{ha})$, available $\mathrm{P}_{2} \mathrm{O}_{5}(37 \mathrm{~kg} / \mathrm{ha})$ and available $\mathrm{K}_{2} \mathrm{O}$ (286 $\mathrm{kg} / \mathrm{ha}$ ) in $0-15 \mathrm{~cm}$ soil depth. There was ten treatments combinations viz., 100\% RDF (25: $50 \mathrm{~N}$ and $\left.\mathrm{P}_{2} \mathrm{O}_{5} \mathrm{~kg} / \mathrm{ha}\right)\left(\mathrm{T}_{1}\right), 50 \% \mathrm{RDN}+50 \%$ $\mathrm{N}$ through FYM $\left(\mathrm{T}_{2}\right), 75 \% \mathrm{RDN}+25 \% \mathrm{~N}$ through FYM $\left(\mathrm{T}_{3}\right), 50 \% \mathrm{RDN}+50 \% \mathrm{~N}$ through vermicompost $\left(\mathrm{T}_{4}\right), 75 \% \mathrm{RDN}+25 \%$ $\mathrm{N}$ through vermicompost $\left(\mathrm{T}_{5}\right), 50 \% \mathrm{RDN}+$ $50 \% \mathrm{~N}$ through FYM + Rhizobium + PSB $\left(\mathrm{T}_{6}\right), 75 \% \mathrm{RDN}+25 \% \mathrm{~N}$ through $\mathrm{FYM}+$ Rhizobium + PSB $\left(\mathrm{T}_{7}\right), 50 \% \mathrm{RDN}+50 \% \mathrm{~N}$ through vermicompost + Rhizobium + PSB $\left(\mathrm{T}_{8}\right), \quad 75 \% \mathrm{RDN}+25 \% \mathrm{~N}$ through vermicompost + Rhizobium + PSB $\left(\mathrm{T}_{9}\right), 100 \%$ $\mathrm{RDF}+$ Rhizobium + PSB $\left(\mathrm{T}_{10}\right)$ were evaluated in randomised block design with four replications. The nutrient sources viz. FYM $\left(0.5 \% \mathrm{~N}, 0.25 \% \mathrm{P}_{2} \mathrm{O}_{5}\right.$ and $\left.0.5 \% \mathrm{~K}_{2} \mathrm{O}\right)$ and vermicompost $\left(3 \% \mathrm{~N}, 1.0 \% \mathrm{P}_{2} \mathrm{O}_{5}\right.$ and $1.5 \%$ $\mathrm{K}_{2} \mathrm{O}$ ) as well as required quantity of nitrogen and phosphorus in the form of urea and single super phosphate were applied as per treatments at the time of sowing. The organic sources of fertilizers i.e FYM and vermicompost were applied 15 days before sowing.

Groundnut variety TG 37 was sown with 100 $\mathrm{kg} / \mathrm{ha}$ seed rate at inter raw spacing of $30 \mathrm{~cm}$ and intra raw spacing of $10 \mathrm{~cm}$ on $19^{\text {th }}$ February 2018. All the cultural operations was carried out as per the recommendation of summer groundnut. Randomly five plants per net plot were selected and tagged for recording the growth and yield attributes characters. The cost of cultivation and returns were calculated by taking account the prevailing cost of inputs and price of produce.

The crop was manually harvested, threshed and pods yield was recorded. The soil sample were collected from each plot after harvesting groundnut crop to a depth of $0-15 \mathrm{~cm}$ and analysed using standard procedure.

The total nitrogen content of pod and haulm of groundnut plants was analysed by micro Kjedahl method and phosphorus by Vanado molybdophosphorus acid yellows colour methods (Jackson, 1967). Total nitrogen values thus obtained were multiplied with a factor of 6.25 to obtain protein content.

The estimation oil content was determined by Soxhlet extraction methods following standard procedure as per Association of Official Analytical Chemists (AOAC, 1970). The total oil yield per hectare was also worked out by multiplying kernel yield ( $\mathrm{kg} / \mathrm{ha}$ ) with oil percent in kernel and divided by 100 .The uptake of nitrogen and phosphorus in pod and haulm were determined by using following formula. 
Nutrient content $(\%)$

$\times$ Kernel yield

$(\mathrm{kg} / \mathrm{ha})$

Nutrients $=$ uptake $(\mathrm{kg} / \mathrm{ha})$

100

\section{Results and Discussion}

\section{Growth parameters}

Fertilizing the groundnut crop with recommended dose of fertilizers along with Rhizobium + PSB recorded significantly taller plants, however plant height in the plot treated with $75 \%$ RDN $+25 \% \mathrm{~N}$ through vermicompost + Rhizobium + PSB and $75 \%$ $\mathrm{RDN}+25 \% \mathrm{~N}$ through FYM + Rhizobium + PSB was more or less equal to the RDF + Rhizobium + PSB treatments. Significant the lower plant height was recorded by the application of $50 \%$ RDN $+50 \% \mathrm{~N}$ through FYM (Table 1).

The effect of FYM and vermicompost in combination with biofertilizers was more pronounced with the advancement of crop growth indicating better effect on periodically plant height upto the harvest of the crop.

This may be owing to continuous availability of nutrition to summer groundnut plants because of slow release of nutrients from FYM and vermicompost during crop season. More over, FYM and vermicompost added NPK in soil, besides the supply of other essential macro and micro nutrients. RDF + Rhizobium + PSB recorded the tallest plant than all other treatments combinations.

The higher number of branches per plant and dry matter accumulation per plant was recorded with $\mathrm{RDF}+$ Rhizobium + PSB followed by $75 \% \mathrm{RDN}+25 \% \mathrm{~N}$ through vermicompost + Rhizobium + PSB and $75 \%$ $\mathrm{RDN}+25 \% \mathrm{~N}$ through FYM + Rhizobium +

PSB. Significantly the lowest number of branches per plant and dry matter per plant was recorded by the application of 50\% RDN $+50 \% \mathrm{~N}$ through FYM. More or less, similar results were obtain on number of root nodules per plant and fresh root nodules weight per plant.

In the present study, better nutrition of the plant owing to FYM, vermicompost and biofertilizers (Rhizobium + PSB) might have resulted in improvement of the number of branches per plant and dry matter per plant.

The association of soil microorganism, organic manures are known to help in synthesis of certain phytohormons and ultimately which promotes the growth and development of crops. The slow release of nutrients due to with FYM and vermicompost might have resulted in higher concentrates of nutrients in plant cell resulting in higher dry matter accumulating per plant.

\section{Yield attributes}

Significantly higher number of pods per plant and dry weight of pods per plant were recorded with combined application of RDF + Rhizobium + PSB followed by 75\% RDN + $25 \% \mathrm{~N}$ through vermicompost + Rhizobium + PSB and $75 \%$ RDN $+25 \% \mathrm{~N}$ through FYM + Rhizobium + PSB. Since the plants were healthy under treatments of having combination of FYM, vermicompost and biofertilizers, they produced more dry matter which was then reflected in their yield attributes viz. number of pods per plant and dry weight of pods per plant.

The minimum number of pods per plant and dry weight of pods per plant were recorded by $\mathbf{5 0} \%$ RDN + 50\% N through FYM. Organic manure did not influence the shelling percentage being varietal characters, which is less sensitive to management levels. 
Table.1 Effect of organic and inorganic sources of nutrients on growth parameters of summer groundnut

\begin{tabular}{|c|c|c|c|c|c|c|c|c|}
\hline \multirow[t]{2}{*}{ Treatments } & \multicolumn{4}{|c|}{ Plant height $(\mathrm{cm})$} & \multirow{2}{*}{$\begin{array}{c}\text { No. of } \\
\text { branches } \\
\text { / plant }\end{array}$} & \multirow{2}{*}{$\begin{array}{c}\text { Dry } \\
\text { matter/ } \\
\text { plant (g) }\end{array}$} & \multirow{2}{*}{$\begin{array}{c}\text { No. of } \\
\text { root } \\
\text { nodules } \\
\text { / plant }\end{array}$} & \multirow{2}{*}{$\begin{array}{c}\text { Fresh root } \\
\text { nodules } \\
\text { weight/ } \\
\text { plant } \\
\text { (mg) }\end{array}$} \\
\hline & $\begin{array}{c}30 \\
\text { DAS }\end{array}$ & $\begin{array}{c}60 \\
\text { DAS }\end{array}$ & $\begin{array}{c}90 \\
\text { DAS }\end{array}$ & $\begin{array}{c}\text { At } \\
\text { harvest }\end{array}$ & & & & \\
\hline $100 \%$ RDF (25:50 N and $\left.\mathrm{P}_{2} \mathrm{O}_{5} \mathrm{~kg} / \mathrm{ha}\right)$ & 9.7 & 21.3 & 35.6 & 38.5 & 7.7 & 35.31 & 27.7 & 107.26 \\
\hline $50 \%$ RDN + 50\% N through FYM & 8.3 & 18.4 & 32.5 & 34.5 & 6.8 & 30.82 & 23.8 & 88.53 \\
\hline $75 \%$ RDN + $25 \% \mathrm{~N}$ through FYM & 9.2 & 21.2 & 35.2 & 38.0 & 7.4 & 35.27 & 27.6 & 106.54 \\
\hline $50 \% \mathrm{RDN}+\mathbf{5 0 \%} \mathrm{N}$ through vermicompost & 8.6 & 19.7 & 33.3 & 35.4 & 7.2 & 31.80 & 27.5 & 104.80 \\
\hline $75 \% \mathrm{RDN}+25 \% \mathrm{~N}$ through vermicompost & 9.3 & 21.3 & 35.2 & 38.0 & 7.5 & 35.28 & 27.7 & 106.80 \\
\hline $50 \%$ RDN + 50\% N through FYM + Rhizobium + PSB & 8.8 & 20.4 & 33.5 & 35.7 & 7.2 & 34.03 & 27.6 & 105.00 \\
\hline $75 \%$ RDN + 25\% N through FYM + Rhizobium + PSB & 10.0 & 22.1 & 37.6 & 41.4 & 8.0 & 39.44 & 29.0 & 112.52 \\
\hline $50 \% \mathrm{RDN}+50 \% \mathrm{~N}$ through vermicompost + Rhizobium + PSB & 9.1 & 20.7 & 34.1 & 36.4 & 7.4 & 35.04 & 27.6 & 105.44 \\
\hline $75 \% \mathrm{RDN}+25 \% \mathrm{~N}$ through vermicompost + Rhizobium + PSB & 10.2 & 22.8 & 38.8 & 42.9 & 8.2 & 39.60 & 29.1 & 113.97 \\
\hline $100 \%$ RDF + Rhizobium + PSB & 10.3 & 23.8 & 39.8 & 44.9 & 8.5 & 40.62 & 31.1 & 117.95 \\
\hline S.Em. \pm & 0.46 & 0.85 & 1.40 & 1.74 & 0.24 & 1.81 & 1.13 & 3.57 \\
\hline C.D. at $5 \%$ & NS & 2.46 & 4.07 & 5.06 & 0.70 & 5.26 & 3.28 & 10.37 \\
\hline C.V. \% & 9.97 & 8.02 & 7.90 & 9.04 & 6.36 & 10.15 & 8.12 & 6.69 \\
\hline
\end{tabular}


Table.2 Effect of organic and inorganic sources of nutrients on yield of summer groundnut

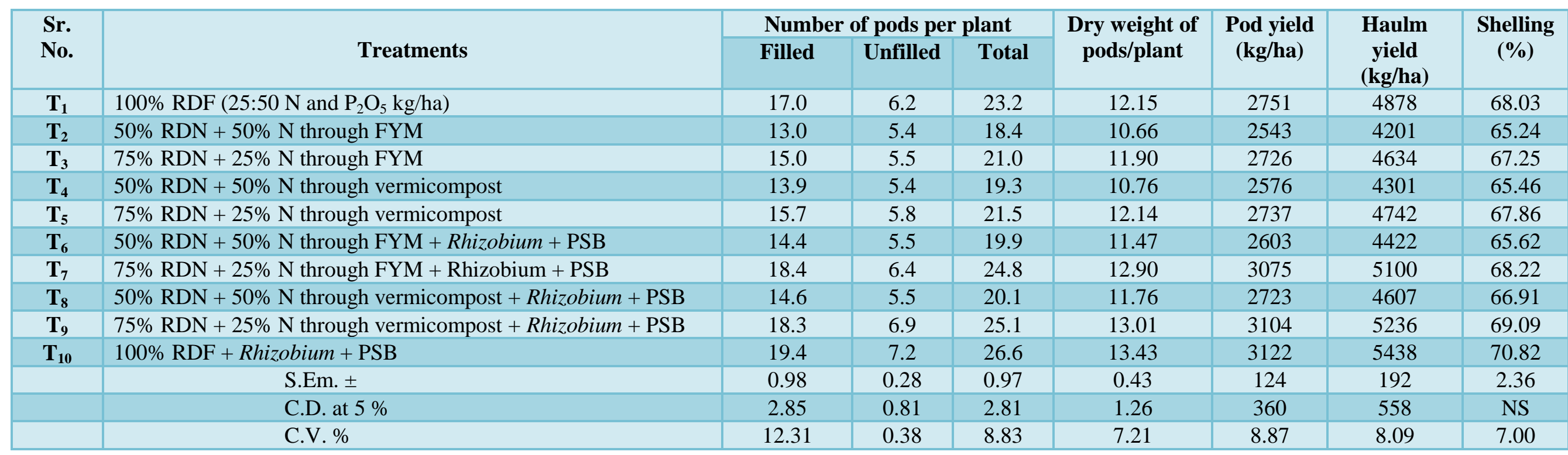

Table.3 Effect of organic and inorganic sources of nutrients on economics of summer groundnut

\begin{tabular}{|c|c|c|c|c|c|}
\hline $\begin{array}{l}\text { Sr. } \\
\text { No. }\end{array}$ & Treatments & $\begin{array}{c}\text { Gross realization } \\
\text { (₹/ha) }\end{array}$ & $\begin{array}{c}\text { Cost of cultivation } \\
(₹ / h a)\end{array}$ & $\begin{array}{c}\text { Net } \\
\text { Realization (₹/ha) }\end{array}$ & BCR \\
\hline $\mathbf{T}_{1}$ & $100 \% \operatorname{RDF}\left(25: 50 \mathrm{~N}\right.$ and $\left.\mathrm{P}_{2} \mathrm{O}_{5} \mathrm{~kg} / \mathrm{ha}\right)$ & 143307 & 55565 & 87742 & 2.57 \\
\hline $\mathbf{T}_{2}$ & $50 \%$ RDN + 50\% N through FYM & 131239 & 56892 & 74347 & 2.31 \\
\hline $\mathbf{T}_{3}$ & $75 \%$ RDN + 25\% N through FYM & 141206 & 56229 & 84977 & 2.51 \\
\hline $\mathbf{T}_{4}$ & $50 \% \mathrm{RDN}+50 \% \mathrm{~N}$ through vermicompost & 133124 & 57892 & 75232 & 2.30 \\
\hline $\mathbf{T}_{5}$ & $75 \% \mathrm{RDN}+25 \% \mathrm{~N}$ through vermicompost & 142133 & 56729 & 85404 & 2.51 \\
\hline $\mathbf{T}_{6}$ & $50 \%$ RDN + 50\% N through FYM + Rhizobium + PSB & 134823 & 57132 & 77691 & 2.36 \\
\hline $\mathbf{T}_{7}$ & 75\% RDN + 25\% N through FYM + Rhizobium + PSB & 158775 & 56469 & 102306 & 2.81 \\
\hline $\mathbf{T}_{8}$ & $50 \% \mathrm{RDN}+50 \% \mathrm{~N}$ through vermicompost + Rhizobium + PSB & 140963 & 58132 & 82831 & 2.43 \\
\hline $\mathbf{T}_{9}$ & $75 \%$ RDN $+25 \% \mathrm{~N}$ through vermicompost + Rhizobium + PSB & 160624 & 56969 & 103655 & 2.82 \\
\hline $\mathbf{T}_{10}$ & $100 \%$ RDF + Rhizobium + PSB & 162242 & 55805 & 106437 & 2.91 \\
\hline
\end{tabular}


Application of fertilizer along FYM and vermicompost increased the number of pods and dry weight of pods per plant significantly, which further increased the pod and haulm yield of summer groundnut. Mohapatra and Dixit (2010) also reported that pods and haulms yield were significantly higher by the application of FYM, Vermicompost and biofertilizers.

An application of recommended dose of fertilizers through various sources (viz. FYM + Vermicompost) along with biofertilizers (Rhizobium + PSB) significantly increased the pod and haulm yield of summer groundnut. The application of RDF along with biofertilizers (Rhizobium + PSB) resulted in significantly highest pod and haulm yield, but it was closely followed by $75 \% \mathrm{RDN}+25 \% \mathrm{~N}$ through vermicompost + Rhizobium + PSB and 75\% RDN $+25 \% \mathrm{~N}$ through FYM + Rhizobium + PSB (Table 2). In case of pod and haulm yield, the latter two treatments in combination of FYM and vermicompost were found statistically alike. This might be attributed to rapid mineralization of nitrogen and slowly supply of nitrogen from FYM and vermicompost along with biofertilizers which might have met the nitrogen requirement of crop at critical stages of growth. Further, FYM and vermicompost act as a nutrient reservoir and upon decomposition produce organic acides, thereby absorbed ions are released slowly during entire growth period leading to improvement in different yield attributes characters and ultimately pod and haulm yield of groundnut. The percent increase in pod yield by fertilizing the crop with $100 \% \mathrm{RDF}+$ Rhizobium + PSB, 75\% RDN $+25 \% \mathrm{~N}$ through vermicompost + Rhizobium + PSB and $75 \% \mathrm{RDN}+25 \% \mathrm{~N}$ through $\mathrm{FYM}+$ Rhizobium + PSB was tune to the tune of 22.8, 22.0 and 20.9 per cent, respectively over $\mathbf{5 0} \%$ RDN $+50 \% \mathrm{~N}$ through FYM. Similar trend was found by Abraham and Thenua
(2010). Dhadge and Satpute (2014) reported significantly higher pod and haulm yield by application of $75 \% \mathrm{RDF}+25 \% \mathrm{~N}$ through FYM + Rhizobium + PSB

\section{Economics}

Significantly higher net realization and net return per rupee invested (BCR) were obtained from the crop fertilized with RDF + Rhizobium + PSB followed by $75 \%$ RDN + $25 \% \mathrm{~N}$ through vermicompost + Rhizobium + PSB and $75 \% \mathrm{RDN}+25 \% \mathrm{~N}$ through FYM + Rhizobium + PSB. The lowest net realization and net return per rupee invested (BCR) were recorded in the $\mathbf{5 0} \% \mathrm{RDN}+50 \% \mathrm{~N}$ through FYM. High cost of FYM and vermicompost resulted in increased the cost of cultivation without too much increase in net returns, thus overall effect of FYM and vermicompost reflected in net returns per rupee increased. The 50\% RDN $+50 \% \mathrm{~N}$ through FYM recorded significantly lower net realization and net return per rupee invested. This result confirms the finding of Datta et al., (2014).

In conclusion the nutshell, fertilizing the groundnut crop either by $100 \% \mathrm{RDF}$ (25:50:00 kg N: $\mathrm{P}_{2} \mathrm{O}_{5}: \mathrm{K}_{2} \mathrm{O} \mathrm{kg} / \mathrm{ha}$ ) along with Rhizobium + PSB or $75 \%$ RDN $+25 \%$ nitrogen either through vermicompost or FYM along with Rhizobium + PSB produced higher yield and monetary returns.

\section{References}

Abraham, T. and Thenua, O.V.S. (2010). Influence of organic and inorganic sources of nutrients and their methods of application on growth and yield attributes of groundnut. Indian Journal of Agricultural Research. 44 (3): 216-220.

AOAC (1970), Association of Official Analytical Chemists.

Datta, M., Yadav, G.S. and Chakraborty, 
Sandip (2014). Integrated nutrient management in sub-tropical humid climate of north-east. India Journal of Agronomy. 59 (2): 322-326.

Dhadge, S.M. and Satpute, N.R. (2014). Effect of integrated nutrient management on growth, yield and quality of summer groundnut. International Journal of Agricultural Science. 10: 314-316.
Gujarat State, Gandhinagar.

Jackson, M.L. (1967). Soil Chemical Analysis, Prentice Hall of India Pvt. Ltd., New Delhi. pp. 327-350.

Mohapatra, A.K.B. and Dixit, L. (2010). Integrated nutrient management in rainy season groundnut. Indian Journal of Agronomy. 55 (2): 123127.

DOA (2018). Directorate of Agriculture,

\section{How to cite this article:}

Joshi, J. P. and Patel, A. G. 2020. Influence of Organic and Inorganic Sources of Nutrients on Growth, Yield and Economics of Summer Groundnut (Arachis hypogaea L.). Int.J.Curr.Microbiol.App.Sci. 9(08): 2169-2175. doi: https://doi.org/10.20546/ijcmas.2020.908.247 